\title{
The Effect Of Tax Avoidance Through Earnings Persistence Against Erc: Evidence From Indonesia
}

\author{
Ali Sandy Mulya \\ Universitas Budi Luhur \\ \{alisandy@outlook.com\}
}

\begin{abstract}
To examine the effect of tax avoidance on earnings response coefficient with earnings persistence as an intervening variable. The independent variable used in this study is tax avoidance. The dependent variable in this research is ERC and earnings persistence as an intervening variable. The population in this study are manufacturing companies listed on the Indonesia Stock Exchange in 2016-2018. The research sample was selected using the purposive sampling method and obtained 55 companies, so the number of samples used was 165 samples. Hypothesis testing uses Partial Least Square. RESULTS: This study shows that tax avoidance has no significant effect on stock values but tax avoidance has a significant effect on earnings persistence. While earnings persistence has a positive effect on stock values, then earnings persistence can mediate the relationship between tax avoidance and ERC. It is expected that the company can be more honest and open, as well as good corporate control. Many ways can be done to streamline and streamline the company's activities, but it should also be noted that there are limitations, because the impact of the company's behavior will be felt again by the company itself both in the long and short term.
\end{abstract}

Keywords: tax avoidance, earnings persistence, ERC.

\section{Introduction}

Capital markets in Indonesia have experienced a rapid increase, especially after the government implemented various regulations in the financial and capital market sectors.[1] The function of the capital market can run effectively if companies incorporated in it can provide financial reports following the rules set by the competent institution. Based on the Financial Services Authority POJK-7, 2018, it is stated that the Financial Services Authority $(\mathrm{OJK})$ as the institution responsible for carrying out this supervision. Financial statements can help investors in making decisions related to investment activities. Investment activities, for example, the decision to hold, sell, or buy investments. Financial statements must be able to provide relevant and reliable information to be used by investors as a basis for decision making. One measure of company performance contained in financial statements and is often used as a basis for decision making by investors is information about company profits [2].

One of the objectives of investors in investing is in companies that are registered in PT Indonesia Stock Exchange.[3] Investors will look for companies that will benefit them, one of 
which is by looking at the returns company's stock. Potential investment returns on the IDX are high as seen from the increase in share prices ranging from $0.31 \%$ to $4,840 \%$ at the end of 2016. The IDX recorded ten shares with the largest increases throughout 2016. This can be seen from the historical statistics of the 10-year CSPI performance last (2009-2018), an investor made a profit of $357.02 \%$ or the equivalent of $8.75 \%$ if it was annualized $16.41 \%$ (versus $131.47 \%$ for 10 years for the period until 2017). IDR 1,000,000 (one million) invested since early 2009 will become IDR 4,570,200 at the end of 2018 (https://www.idx.co.id/).

The high return on the IDX and the ever-increasing JCI make the investment increase in Indonesia. High stock returns and JCI which continues to soar will affect the quality of company profits or in other words, the high ERC is influenced by the magnitude of stock returns and the value of the CSPI. Investors must be more observant in evaluating information submitted by issuers or public companies. Companies that generate high profits, of course, become one that is targeted by investors with the hope that they will get a high return. The evaluation of earnings is not only from the nominal shown by the profit account but involves other variables that influence it [4].

The problem of earnings is closely related to the expenses incurred by the company because the efficiency of expenses or expenses is directly related to earnings. Companies always try to minimize the expenses incurred by the company, for example, the tax burden.[5] Corporate tax is very influential for the survival of the company, because the tax company will reduce the amount of net profit to be obtained by the company so that it allows the company to pay as low as possible [6]. That agency theory there are differences in views between regulators in this case represented by the Directorate General of Taxation with corporate management regarding taxation, causing many companies when they have a high tax burden will tend to encourage management to do profit manipulation and tax planning. [7] Tax planning is one form of tax management that companies can do. For management in general, tax planning is not mere intuition because it is based on a variety of clear concepts and goals. The purpose of tax planning is to minimize the burden or tax owed both in the current year or for the following years [8].

Tax avoidance is an important strategy in the company.[9] Traditionally it is believed that the practice of tax avoidance corporate shows the transfer of wealth from the government to the company and will increase the value of the company. One understanding of tax avoidance is "arrangement of a transaction to obtain a tax advantage, benefit, or reduction in a manner unintended by the tax law". ([10] Based on this understanding, it can be said that tax avoidance is used by companies to obtain profits, benefits, or reduction of taxes imposed, so companies can minimize tax obligations. That Tax avoidance affects the relevance of investor assessments on the announcement date which is evaluated through ERC. The ERC reflects the level of market participant's confidence in earnings quality and therefore represents a perspective of earnings quality based on market performance [11][12]. The strong market reaction to earnings information is reflected in the high value of ERC, indicating that the market evaluates reported good quality earnings [13]. Conversely, the weak market reaction to earnings information is reflected in the low value of the ERC, indicating that the market assesses earnings reported to be of poor or poor quality.[14] ERC is a proxy of a company's stock value. The higher the value of ERC means the better the investor's assessment of the value of its shares and vice versa [14]. define an earnings response coefficient measures the extent of a security's abnormal market return in response to the unexpected component of reported earnings of the firm issuing that security. ERC measures changes in abnormal returns in response to unexpected components of the company's announced earnings. 
[15]Examines how the market reacts to action tax avoidance taken by companies, showing that actions tax aggressiveness can increase or decrease the value of company shares, such as those of Apple Inc., Starbucks, Amazon, Skype, and Facebook. In Indonesia alone, it is estimated that many companies also practice tax avoidance, for example manufacturing companies. There are cases of tax avoidance manufacturing companies in Indonesia carried out by PT. Toyota Motor Manufacturing Indonesia (TMMIN) in 2013. This TMMIN case occurred because of the separation of a manufacturing company the TMMIN flag, while the distribution and marketing department was under the TAM flag. The cars produced by TMMIN are sold first to TAM, then from TAM sold to Auto 2000 and then sold to consumers. This caused a $7 \%$ reduction in gross margin, which should have been combined to get a gross margin of $14 \%$. For this reason, the Director-General of Taxes questioned where this $7 \%$ gross margin would run.

[14] ERC is influenced by things like beta, capital structure, earnings quality, earnings persistence, growth opportunities, the similarity of investor expectations, and the informativeness of price. Other studies on ERC have been carried out, but the results are still not consistent. [16][17][17][18], support the existence of a positive relationship between ERC and earnings persistence [19][20]. who concluded that there is no relationship between earnings persistence and ERC. Whereas research on BTD was conducted. [21] as one indicator in predicting earnings persistence, cash flow, and accruals in the future. The results of this study prove that companies with large BTD tend to be less persistent in their profits compared to companies with smaller BTD.

\section{Literature Review}

\subsection{Efficient Market Theory}

Rreveals that an efficient market is a market where the prices of all traded securities reflect all available information.[22] If the market is efficient and all information can be obtained easily and at low cost by all parties in the market, then no investor will get an abnormal return. The capital market is said to be efficient in terms of information if the market price has full implications for the return of that information [23][24][25][26] classifies efficient market forms into three Efficient Market Hypotheses (EMH), namely: (i) Efficient in a weak form, which states that stock prices have reflected all information that can be derived by examining market trading data in the form historical prices, trading volume, and loan interest. (ii) Semi strong efficiency states that all publicly available information about a company's prospects should be reflected in stock prices. Whereas EMH which (iii) Strong efficiency-form, wherein the strong form, all information either published or unpublished, is already reflected in the current price of securities.

In the theory of efficient markets, accounting information is in a position to compete with other information sources such as the news media, a financial analyst, and even the price of the penny-yourself market. As a tool or a means to convey information to investors, the accounting information will be useful only if the information is relevant, reliable, timely, and saving(cost-effective) as well as relative when compared with the resources the other. 


\subsection{Agency Theory}

Referring to [7] agency relationship as a contract in which one or more principals appoint agents to perform services for the principal's interests which includes delegating decisionmaking power to agents. Both principals and agents are assumed to be rational economic people and are solely motivated by self-interest. The essence of the agency relationship is the separation between the principal and the manager. Investors expect that managers will produce returns the desired. This agency theory view results in conflicts that can affect the quality of reported earnings because management who has certain interests such as management has the desire to maximize bonus costs, but the investors want to minimize the bonus costs. This will cause management to tend to prepare earnings reports following its objectives and not for the benefit of shareholders.

\subsection{Earnings Response Coefficient (ERC)}

Earnings have different qualities, this can be shown from the high when the market responds to earnings information. Market response in response to profits generated by a company affects market decisions in making decisions, especially in investing. Generally in knowing the strength of the relationship between accounting earnings and stock prices, ERC is used in the accounting and financial literature. According to Scott, WR \& O'Brien, P. ERC measures the extent of a security's abnormal market return in response to the unexpected component of reported earnings from the firm issuing that security.[14] ERC measures the magnitude of the abnormal return markets in response to the surprise component of earnings reported by the company that issued the security. While unexpected earnings according to Suwardjono is the difference between expected earnings and reported or actual earnings.[27] Surprise earnings represent information that has not been captured by the market so that the market will react at the time of the announcement. Earnings in an analysis like this are usually earnings per share for a particular company.

The market reaction indicated by the change in the market price return certain companies are quite striking at the time of the earnings announcement that there is a considerable difference occurs returns (actual return) to return (expected return). Another term, there is a return surprise or abnormal (unexpected or abnormal return) at the time of earnings announcements [27] ERC can also be a coefficient that shows how much investor response is reflected in changes in stock returns to earnings information contained in financial statements. If the ERC value is positive, it indicates that the response of investors increases to earnings information, whereas if the ERC value is negative, it indicates that the response of investors is decreased to the earnings information of a company. Thus, ERC is calculated using the following formula: 
A. Daily abnormal return is calculated by the formula:

$\mathrm{AR}_{\mathrm{it}}=\mathrm{R}_{\mathrm{it}}-\mathrm{RM}_{\mathrm{it}}$

Note:

$\mathrm{AR}_{\mathrm{it}}=$ abnormal return of shares to $\mathrm{i}$ on day $\mathrm{t}$

$\mathrm{R}_{\mathrm{it}}=$ return of shares to $\mathrm{i}$ on period $\mathrm{t}$ day

$\mathrm{RM}_{\mathrm{it}}=$ market return to $\mathrm{i}$ on day $\mathrm{t}$

While for daily stock returns calculated by the formula:

$\mathrm{R}_{\mathrm{it}}=\left(\mathrm{P}_{\mathrm{it}}-\mathrm{P}_{\mathrm{it}-1}\right) / \mathrm{P}_{\mathrm{it}-1}$

Note:

$\mathrm{R}_{\mathrm{it}}=$ stock return $\mathrm{i}$ in the period $\mathrm{t}$ day

$\mathrm{P}_{\mathrm{it}}=$ closing price of stock $\mathrm{i}$ on day $\mathrm{t}$

$\mathrm{P}_{\mathrm{it}-1}=$ closing price of stock $\mathrm{i}$ on day $\mathrm{t}-1$

Market return (RMit) is calculated using the formula:

$\mathrm{RM}_{\mathrm{it}}=\left(\mathrm{JCI}_{\mathrm{it}}-\mathrm{JCI}_{\mathrm{it}-1}\right) / \mathrm{JCI}_{\mathrm{it}-1}$

Note:

$\mathrm{RM}_{\mathrm{it}}=$ market return $\mathrm{i}$ on the day $\mathrm{t}$ period

$\mathrm{JCI}_{\mathrm{it}}=$ gabugan stock price index on the $\mathrm{t}$ day $\mathrm{t}$

$\mathrm{JCI}_{\mathrm{it}-1}=$ composite stock price index on day $\mathrm{t}-1$

B. Calculating Cummulative Ab normal Return (CAR)

CAR is obtained by summing the company's abnormal return i throughout the window period.

$\mathrm{CAR}_{\mathrm{it}}=\Sigma \mathrm{AR}_{\mathrm{it}}$

Note:

$\mathrm{CAR}_{\text {it }}=$ Cummulative Abnormal Return of the company i during the window period for a day around date of announcement of annual financial statements

$\mathrm{AR}_{\mathrm{it}}=$ abnormal return of shares to $\mathrm{i}$ during the window period

C. Calculating Unexpected Earnings (EU)

$\mathrm{EU}_{\mathrm{it}}=\left(\mathrm{AE}_{\mathrm{it}}-\mathrm{AE}_{\mathrm{it}-1}\right) / \mathrm{AE}_{\mathrm{it}-1}$

Description:

$\mathrm{EU}_{\mathrm{it}}=$ Unexpected Earnings of company $\mathrm{i}$ in period $\mathrm{t}$

$A E_{i t}=$ Accounting profit after corporate tax $i$ in year $t$

$A E_{i t-1}=$ Accounting profit after company tax $i$ in year $t-1$

D. Calculate ERC by using regression

$\mathrm{CAR}=\beta \mathrm{o}+\beta 1(\mathrm{EU})+\mathrm{e}$

Note:

$\mathrm{CAR}=$ Cumulative Abnormal Return of company $\mathrm{i}$ during the period of the window

$\mathrm{EU}=$ Unexpected earnings of company $\mathrm{i}$ in year $\mathrm{t}$

$\beta 0=$ Constant

$\beta 1=$ surprise earnings coefficient (ERC)

$\mathrm{e}=$ component error, i.e. error rate estimator in research

\subsection{Tax Avoidance (Tax A)}

Refers to Dyreng, et. al and Kanagaretnam, et al. tax avoidance is all forms of activities that give effect to tax obligations, both activities permitted by tax or special activities to reduce taxes. Usually, Tax avoidance is done by exploiting the weaknesses of tax law and does not violate taxation laws.[28] Whereas the OECD fiscal committee (Spitz, 1983) has three characteristics of tax avoidance, namely: (a) artificial arrangements, where various 
arrangements appear to be in them when they are not, and this is done because of the absence of tax factors, (b) loopholes of the law or applicable legal provisions for various purposes, which are contrary to the actual contents of the law, and the last character (c) There is an element of confidentiality, this is designated by the company to take care of the company's tax shows how tax avoidance is done on condition that the taxpayer must keep the confidentiality as deep as possible. In theory, the factors that influence individual tax compliance are determined by tax rates, the possibility of tax avoidance, penalties, penalties, and risk aversion. [21] According to Slemrod and Hanlon, M. \& Heitzman, S., Hanlon, M. \& Heitzman, S., an additional factor for companies to comply with taxes is the separate ownership and control in the company. [29][21] This can lead to corporate tax decisions that reflect management interests, based on the authors use the book-tax differences, which are formulated as follows:

BTD $=\frac{\text { Book Income it-Taxable Income it }}{\text { Total Asset it }}$

\subsection{Earnings Persistence (PL)}

Profit is an indicator of the success of a business entity or entity, because the higher the profits obtained, the higher the success achieved. Profit is the main goal to be achieved either by the business entity itself or parties who will become investors or creditors or parties who have other interests for the business entity because profit is one of the indicators that they pay attention to. Scott, WR \& O'Brien, P. Earnings persistence is a revision of expected future earnings (implied) which is implied by current year's earnings innovation so that earnings persistence is seen from current year earnings innovations that are associated with changes in stock prices. Earnings persistence is measured using a regression coefficient between current period earnings and past period earnings.[14] The higher the number approaching 1 (one) coefficient indicates the high persistence of the resulting profit, conversely if the coefficient value is close to 0 (zero), the earnings persistence is low. If the coefficient value is negative, the meaning is reversed, ie higher coefficient values indicate less persistence, and lower coefficient values indicate more persistence. Thus, earnings persistence is calculated using the following formula:

$\frac{\text { PL(it-PL it-1) }}{(\text { PL it-1) }}$

\subsection{The conceptual framework}

It is an overview of the relationship between variables to be studied as described in the above theoretical basis [30] can be seen in the picture below:

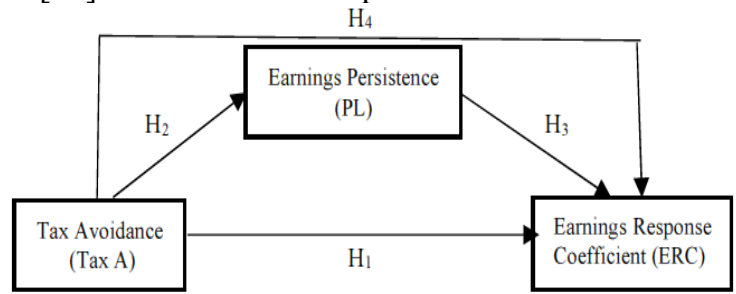

Fig. 1. The Relationship Between Variables to be Studied 


\subsection{Research Hypothesis Development}

Based on the formulation of the problem, the theoretical basis and framework above, it can be arranged hypothesis [30] of analysis of Tax A effect on ERC with PL as an intervening variable: (1) Effect of direct Tax A on ERC ; (2) Effect of Tax A on PL ; (3) Effect of PL on ERC ; (4) The indirect effect of Tax A on ERC through PL as an intervening variable.

\section{Method of Research}

\subsection{Population, Sample Selection Method, and Variable Measurement}

The population in this study are manufacturing companies listed on the Indonesia Stock Exchange (IDX) in the period 2016-2018. The reason is that the practice of tax avoidance is mostly done in companies that in their activities manage raw materials to become finished goods. The manufacturing sector produces many excellent companies whose products are consumed by the people of Indonesia so that this causes most investors to invest a lot in capital manufacturing and tax avoidance practices are also carried out by many manufacturing companies. This type of research is a quantitative research and hypothesis testing using the method Partial Least Square with Warp PLS. This research is research that as the objective to analyze the influence of one variable with another variable or how a variable can affect other variables through intervening variables. In this case, the researcher wants to explain the Tax A affecting ERC where PL is an intervening variable.

\subsection{Research}

Model the SEM model in Appendix-1 presents the relationship between variables Tax A, PL, and ERC. In this study can use path analysis with multiple regression techniques, but the path analysis must be done simultaneously. If you use several regression equations and estimate them gradually, this is because regression analysis is limited to only one dependent path. The gradual path analysis cannot test the SEM model as a whole. whereas in this study earnings persistence variables can act as both independent and dependent variables. The advantage of SEM, in this case, is being able to estimate the model simultaneously so that it is more precise in testing the theory and helping researchers conclude whether the model according to the theory is supported by the data.

\subsection{Operational Variables}

The research uses three research variables namely Tax A, PL, and ERC, the following are operational variables:

Table 1. Operational Variables

\begin{tabular}{|c|c|c|c|c|}
\hline Variable & Dimension & Proxy & Scale & Source \\
\hline $\begin{array}{l}\text { Tax Avoidance } \\
\text { (X) }\end{array}$ & Book Tax Differences & $\frac{\text { Book Income it - Taxable Income it }}{\text { Total Asset it }}$ & Ratio & $\begin{array}{l}\text { Financial } \\
\text { statements }\end{array}$ \\
\hline $\begin{array}{c}\text { Earnings } \\
\text { Persistence (Z) }\end{array}$ & $\begin{array}{l}\text { Change in profit } \\
\text { in the future seen from the } \\
\text { present profit }\end{array}$ & $\frac{\text { PL it }-(P L i t-1)}{(P L i t-1)}$ & Ratio & $\begin{array}{l}\text { Financial } \\
\text { statements }\end{array}$ \\
\hline $\begin{array}{c}\text { Earnings } \\
\text { Response } \\
\text { Coefficient }(\mathrm{Y})\end{array}$ & $\begin{array}{l}\text { The regression coefficient } \\
\text { of abnomal retums of } \\
\text { stocks and unexpected } \\
\text { earnings }\end{array}$ & $\begin{array}{l}\mathrm{AR}_{\mathrm{it}}=\mathrm{R}_{\mathrm{it}}-\mathrm{RM}_{\mathrm{it}} \\
\mathrm{CAR}_{\mathrm{it}}=\sum \mathrm{AR}_{\mathrm{it}} \\
\mathrm{UE}_{\mathrm{it}}=\left(\mathrm{AE}_{\mathrm{it}}-\mathrm{AE}_{\mathrm{it}} \mathrm{I}\right) / \mathrm{AE}_{\mathrm{it}-\mathrm{t}} \\
\mathrm{CAR}=\beta 0+\beta \mathrm{l}(\mathrm{UE})+\mathrm{e}\end{array}$ & Ratio & $\begin{array}{l}\text { Financial } \\
\text { statements }\end{array}$ \\
\hline
\end{tabular}




\subsection{Hypothesis Testing}

To test hypotheses about causality developed in this model, the magnitude of the value of p. The value in the range index is the basis of the significance of the relationship between exogenous and endogenous latent variables where $p$-value $\geq 0.05$ is said to be insignificant, and $p$-value $<$ of 0.5 is said to be significant. The p-value of value is used in accepting and rejecting the hypothesis, the real rate is p-value $>0.05$ then the hypothesis is rejected while the p-value $<0.05$ then the hypothesis is accepted.[31]

\subsection{Direct Influence}

Testing direct and indirect effects are used to determine the strength of the influence between constructs, both direct and indirect effects, direct effects are all coefficient lines with one end arrow (loading factor) of each indicator variable which forms the latent variable analyzed. In this research, we will see the direct effect of (1) Tax A on ERC, (2) Tax A on PL, (3) PL on ERC, and (4) Testing the effect of indirect (intervening analysis). Mediation effects is a relationship that occurs between exogenous constructs and endogenous constructs that occur indirectly. This indirect relationship arises due to exogenous constructs in influencing endogenous constructs through other constructs called connecting or intermediate constructs[31] This means that the influence of exogenous constructs on endogenous constructs can be directly or through connecting constructs. Meanwhile, according to Hair, et al. analysis of mediating variables can be done through the coefficient difference approach. This approach uses the inspection method by analyzing with and without involving mediation variables [32].

\section{Analysis and Discussion}

\subsection{Descriptive Statistics}

In the process of collecting data in this study using some software that can help the writer in processing data with the reasons for efficient and effective research. Some of the software these include SPSS 22 and Microsoft Excel 2010, which helps the author in tabulating data. While Warp PLS 5.0 helps the author in processing data that was previously in the form of a simple tabulation.

The number of observations used in this study was 165 , consisting of 55 companies in the period from 2014 to 2016. Samples were obtained from manufacturing companies listed on IDX. The independent variable used in this study is Tax A and the dependent variable used is the ERC. While PL is used as an intervening variable. The following discusses the descriptive statistical results shown in appendix-3 measurements Tax A show the average Book Tax Difference (BTD) of 0.0247 while the BTD standard deviation of 0.04616 means the difference between the required data and the data taken as a sample the amount is 0.04616 so that the sample data taken can represent the needs of the existing data. PL measurement shows an average PL of 0.0849 while the standard deviation of 5.48143 means the difference between the required data and the data taken as a sample is 5.48143 so that the sample data taken can represent the need for existing data. 
The measurement ERC shows the average cumulative abnormal return (CAR) of 0.0331 while the standard deviation of CAR of 0.07089 means the difference between the required data and the data taken as a sample is 0.07089 so that the sample data taken can represent the need existing data. The average Unexpected Earnings (EU) is 0.0849 while the EU standard deviation is 5.48143 so that the sample data taken can represent the need for existing data.

\subsection{T-Test}

According to Priyatno, D. t-test (partial regression coefficient test) is used to determine the effect of the dependent variable partially, whether it has a significant effect or not.[33] Basic testing criteria are as follows:

a) Ho is accepted and $\mathrm{Ha}$ is rejected if $\mathrm{P}$-value (sig) $>$ alpha $0.05(5 \%)$, so that part there is no significant effect of $\mathrm{X}_{1}$ on $\mathrm{X}_{2}$ and $\mathrm{X}_{1} \& \mathrm{X}_{2}$ on $\mathrm{Y}$.

b) Ho is rejected and $\mathrm{Ha}$ is accepted if the $\mathrm{P}$-value (sig) <alpha $0.05(5 \%)$, so there is a significant influence of $\mathrm{X}_{1}$ against $\mathrm{X}_{2}$, and $\mathrm{X}_{1} \& \mathrm{X}_{2}$ against $\mathrm{Y}$.

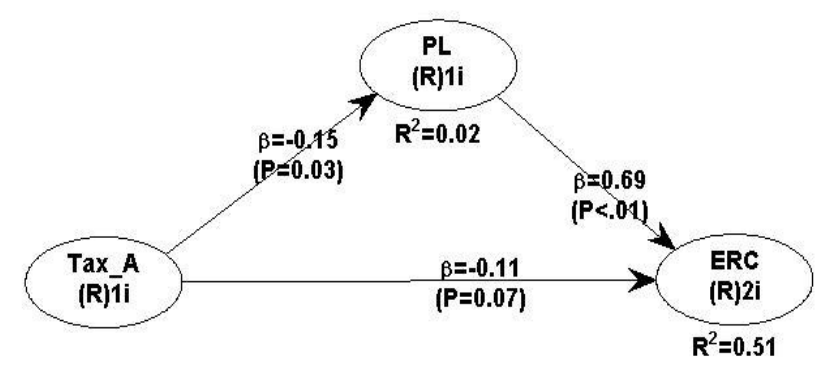

Fig. 2. Test Results Hypothesis

Table 2. Test $\mathrm{T}$

\begin{tabular}{|c|c|c|c|}
\hline Path & Coefficients & P-values & Results \\
\hline Tax A $\rightarrow$ ERC & -0.115 & 0.067 & Ha: Rejected \\
\hline Tax A $\rightarrow$ EP & -0.145 & $0.028^{*}$ & Ha: No Rejected \\
\hline EP $\rightarrow$ ERC & 0.694 & $<0.001^{*}$ & Ha: No Rejected \\
\hline
\end{tabular}

Source: Data processed by WarpPLS 5.0

\subsection{Testing of Effect Direct}

a) Testing the first hypothesis (H1) the effect of Tax A on ERC. Path Coefficient and Pvalue show that Tax A has an insignificant effect on ERC because it has a P-value of $0.067>0.05$ with a path coefficient of -0.115 or in words others Ho is accepted (Ha rejected) which means there is an influence but not significant between Tax A and ERC.

b) Testing the second hypothesis (H2) the effect of Tax A on PL. Path Coefficient and Pvalue shows that Tax A has a significant negative effect on PL because it has a P-value of $0.028<0.05$ with a path coefficient of -0.145 or with other words Ho is rejected (Ha accepted) which means there is a significant influence between Tax A on the PL.

c) The third hypothesis testing (H3) the effect of PL on ERC. Path Coefficient and P-value show that PL has a significant effect on ERC with a P-value $<0.001<0.05$ and the value 
path coefficient of 0.694 or in other words Ho is rejected (Ha accepted) which means that there is a significant influence between PL on ERC.

\subsection{Testing for Indirect Effects}

Analysis of mediating variables can be done through two approaches namely coefficient differences and coefficient multiplication. The coefficient difference approach uses the inspection method by analyzing with and without involving mediation variables. While the multiplication method is done by the Sobel method. Examination method by conducting two analyzes, namely analysis involving mediation variables and analysis without involving mediation variables.

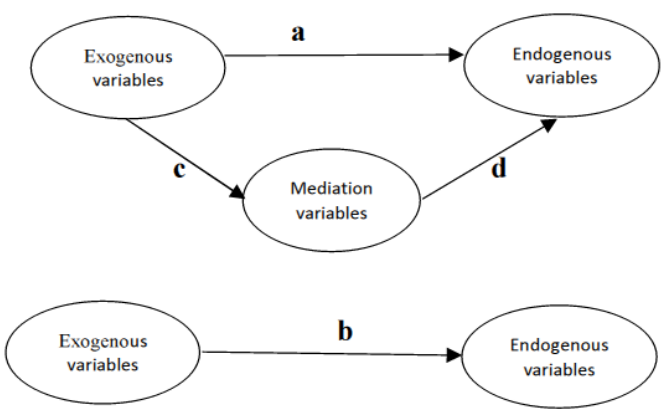

Fig. 3. Mediation Test

If (c) and (d) are significant, and (a) not significant, then the mediating variable is said to be the variable complete mediation. If (c) and (d) are significant and (a) also significant, where the coefficient of (a) is smaller (down) than (b) then the mediating variable is said to be a variable partial mediation. If (c) and (d) are significant and (a) also significant, where the coefficient of (a) is almost the same as (b) then the mediating variable is said not to be a mediating variable. If either (c) or (d) or both are insignificant then it is not said to be a mediating variable [32]. Conclusions about the effects of mediation can be done with the following steps:

a) If the path coefficients of Tax $\mathrm{A} \rightarrow \mathrm{PL}$ and PL $\rightarrow$ ERC are significant, and the direct effect of Tax A $\rightarrow$ ERC is not significant and the indirect effect of Tax A $\rightarrow$ ERC is significant then the form of mediation is full mediation (full mediation).

b) If the path coefficients of Tax $\mathrm{A} \rightarrow \mathrm{PL}$ and PL $\rightarrow$ ERC are significant, and the direct effect of Tax A $\rightarrow$ ERC is significant and the indirect effect is significant but the coefficient value is down, then the form of mediation is partial mediation.

c) If the path coefficients of Tax A $\rightarrow$ PL and Tax A $\rightarrow$ ERC and PL $\rightarrow$ Tax A from the estimation results of the model remain significant, then the direct effect of Tax $\mathrm{A} \rightarrow$ ERC is significant and the coefficient values are the same, then the mediating effect is absent.

d) If the path coefficients of Tax A $\rightarrow$ PL and PL $\rightarrow$ ERC from the estimation results of one or both models are not significant, then there is no mediating effect. The results of testing the mediating effect of the indirect effect of Tax A on the ERC mediated by the PL can be seen in the table below. 
Table 3. ERC mediated by the PL

\begin{tabular}{|c|c|c|c|c|c|c|}
\hline \multirow{2}{*}{ Path } & \multicolumn{2}{|c|}{ Direct Influence } & \multirow{2}{*}{ Results } & \multicolumn{2}{|c|}{ In-Direct Influence } & \multirow{2}{*}{ Results } \\
\hline & Coef. & P-values & & Coef. & P-values & \\
\hline $\begin{array}{c}\text { Tax_A } \rightarrow \\
\text { ERC }\end{array}$ & -0.115 & 0.067 & $\begin{array}{c}\text { no- } \\
\text { significant }\end{array}$ & -0.101 & 0.032 & significant \\
\hline Tax_A $\rightarrow$ PL & & & & -0.145 & 0.028 & significant \\
\hline $\mathrm{PL} \rightarrow \mathrm{ERC}$ & & & & 0.694 & $<0.001$ & significant \\
\hline
\end{tabular}

The results of testing the mediation effects in table 4.6 above show that the beta coefficient direct effect Tax $\mathrm{A} \rightarrow$ ERC of -0.115 is not significant with a P-value of $0.067>0.05$. And the coefficient of indirect effect Tax $\mathrm{A} \rightarrow$ ERC becomes -0.101 significant with a P-value of 0.032 $<0.05$, thus the requirements for mediation testing have been fulfilled in the form of full mediation, due to the direct effect of Tax $\mathrm{A} \rightarrow$ ERC is not significant and effect indirect TAX $\rightarrow$ ERC is significant, then Tax $\mathrm{A} \rightarrow \mathrm{PL}$ and PL $\rightarrow$ ERC is significant. Based on the test results above, it can be said that the PL mediates the effect of Tax A on ERC in other words Ho is rejected (Ha is accepted).

\subsection{Interpretation of Research Results}

\section{a) The Effect of Tax Avoidance on ERC}

Based on the results of tests that have been carried out it is known that tax avoidance has no significant effect on ERC. It can be concluded that the H1 hypothesis is rejected, ie there is no effect of tax avoidance on ERC. This means that a high level of tax avoidance does not affect ERC. The results of this study are in line with research Desai, M.A. \& Dharmapala, D. (2009), and Jonathan and Tandean, V.A. (2016) but not in line with Chasbiandani, T. \& Martani. D. (2012) which provides evidence that tax avoidance affects the value of the company where the value of the company is the same as ERC because it is an investor's reaction in responding to the actions tax avoidance taken by the company.

The absence of a significant effect between tax avoidance on ERC can occur because of the tendency of investors to not see how much tax is paid by the company so that it does not consider the amount of tax avoidance committed by the company. Investors generally prefer to invest in companies whose profits are stable or high. So thus, the presence or absence of actions tax avoidance in the company does not affect investors' decisions in investing. So that investors will not withdraw their investment even though the company is doing tax avoidance.

\section{b) Effect of Tax Avoidance on Earnings Persistence}

Hypothesis testing results show that tax avoidance has a negative and significant effect on earnings persistence. Then it can be concluded that the $\mathrm{H} 2$ hypothesis is accepted, namely, there is an effect of tax avoidance on earnings persistence. This means that the size of the value tax avoidance affects earnings persistence. [34] which provides evidence that tax avoidance by companies is aggressive and this is possible because the income and costs that form fiscal profits, affect the revision of future earnings. 


\section{c) Effect of Earnings Persistence on ERC}

Based on the results of tests that have been done, it is known that earnings persistence has a significant effect on ERC. Then it can be concluded that the hypothesis H3 is accepted, that there is an effect of earnings persistence on ERC. This means that a high level of earnings persistence affects ERC. The results of this study are in line with research by Kormendi, R and Lipe, R. (1987), Collins, DW, and SP Kothari. (1989), Sri, M. \& Nur, F. (2007), and Palupi, MJ (2006) provide evidence that earnings persistence has a positive effect on ERC. This shows that the profits derived by these companies can increase continuously or stable in the future.

\section{d) Effect of Tax Avoidance on ERC through Earnings Persistence}

Based on statistical tests showing that the Profit Persistence variable can mediate the effect of Tax Avoidance on Earnings Response Coefficient, the H4 hypothesis is accepted, in the form of full mediation (full mediation), due to the effect of direct effect is Tax A $\rightarrow$ ERC not significant and the effect of indirect Tax $\mathrm{A} \rightarrow$ ERC is significant, then Tax $\mathrm{A} \rightarrow \mathrm{PL}$ and PL $\rightarrow$ ERC is significant. So there is the influence of Tax A on ERC with PL mediation. This shows that Tax A will affect the ERC if the tax avoidance by the company can affect the persistence of the company's profits in the future and this will affect the valuation of investors.

\section{Conclusion}

This study aims to determine the effect of tax avoidance on ERC with Profit Persistence as a variable intervening. The population of this study is manufacturing companies listed on the Indonesia Stock Exchange from 2014 to 2016. The research sample was selected using a purposive sampling technique to obtain 55 companies that met the criteria, with a total sample of 165 data. Hypothesis testing using Partial Least Square with Warp PLS 5.0. Based on the results of the research that has been done, several conclusions can be drawn, namely:

a) Variable tax avoidance does not affect ERC. The results of this study are in line with research conducted by Desai, MA \& Dharmapala, D. (2009), and Jonathan and Tandean, VA (2016). But not the following research was conducted by Chasbiandani, T. \& Martani. D. (2012). This can occur because of the tendency of investors to not see how much tax is paid by the company so that it does not consider the amount of tax avoidance done by the company.

b) Variable tax avoidance affects earnings persistence. The results of this study are in line with the research of Martani, D. (2010) but not in line with research by Prasetyo, et al. (2015).

c) Variable Earnings persistence influences ERC. The results of this study are in line with research by Kormendi, R and Lipe, R. (1987), Collins, DW, and SP Kothari. (1989), Sri, M. \& Nur, F. (2007), and Palupi, MJ (2006).

d) The test results state that the earnings persistence variable can mediate the relationship of tax avoidance to ERC. This shows that Tax A will affect the ERC if the tax avoidance by the company can affect the persistence of the company's profits in the future and this will affect the valuation of investors. 


\section{Continuous, Limitation \& Study}

This study has limitations because it uses a manifest of tax avoidance, and is only carried out in issuers in the manufacturing sector and the observation period of this study is only 3 years. Researchers can then use measurement tax avoidance other such as long-run tax avoidance, cash-ETR, etc. If you want to use BTD, data should be grouped into large positive (negative) and small BTD to make it more visible for companies that are implementing tax avoidance practices aggressively.

\section{Appendix}

Table 4. Appendix 1 Descriptive statistics

\begin{tabular}{|l|c|c|c|c|c|}
\hline & \multicolumn{1}{|c|}{$\mathrm{N}$} & Min & Max & Mean & Std. Deviation \\
\hline TAX AVOIDANCE & 165 & -.06 & .18 & .0247 & .04616 \\
Book Tax Difference (BTD) & 165 & -34.50 & 52.73 & .0849 & 5.48143 \\
EARNINGS PERISTENCE & 165 & -.21 & .48 & .0331 & .07089 \\
Eamings Persistence (PL) & 165 & -34.50 & 52.73 & .0849 & 5.48143 \\
EARNING RESPONSE COEFFICIENT & & & & \\
Cummulative Abnormal Retum (CAR) & Unexpected Eamings (UE) & & & & \\
Valid N (listwise) & & &
\end{tabular}

Table 5. Appendix 2

Combined loadings and cross-loadings

\begin{tabular}{|l|c|c|c|c|c|}
\hline & Tax A & PL & ERC & P value & Results \\
\hline BTD & 1.000 & 0.000 & 0.000 & $<0.001$ & Valid \\
\hline PL & -0.000 & 1.000 & -0.000 & $<0.001$ & Valid \\
\hline ERC & 0.000 & -1.000 & 0.706 & $<0.001$ & Valid \\
\hline UE & -0.000 & 1.000 & 0.706 & $<0.001$ & Valid \\
\hline
\end{tabular}

Source: Data processed by WarpPLS 5.0

Table 6. Appendix 3

\begin{tabular}{|l|c|c|c|c|c|c|}
\hline & $\begin{array}{c}\text { Composite } \\
\text { Reliability } \\
\text { coefficients }\end{array}$ & $\begin{array}{c}\text { Results } \\
\text { CR }>0,7\end{array}$ & $\begin{array}{c}\text { Cronbach's } \\
\text { Alpha } \\
\text { coefficients }\end{array}$ & $\begin{array}{c}\text { Results } \\
\text { CA }>0,7\end{array}$ & $\begin{array}{c}\text { Average } \\
\text { Variances } \\
\text { extracted }\end{array}$ & $\begin{array}{c}\text { Results } \\
\text { AVE }>0,50\end{array}$ \\
\hline Tax_A & 1.000 & Reliable & 1.000 & Reliable & 1.000 & Reliable \\
\hline EP & 1.000 & Reliable & 1.000 & Reliable & 1.000 & Reliable \\
\hline ERC & 0.666 & No Reliable & -0.004 & No Reliable & 0.499 & No Reliable \\
\hline
\end{tabular}

\section{References}

[1] R. Armansyah, 'The Disposition effects on the Financial Crisis of the Indonesia Capital Market', JMK, vol. Vol. 20, no. No. 2,.

[2] E. E. Blessing, A. \& Onoja, 'The Role of financial statement on investment decision making: A Case of United Bank for Africa PLS.', Eur. J. Business, Econ. Accountancy, vol. Vol 3., no. No.2., 2015.

[3] G. \& H. E., 'Stock liquidity and market capitalization: Investment challenges in Indonesia Capital Markets', SSRG Int. J. Econ. Manag. Stud., vol. Vol. 5, no. Issue 11. 
[4] et al. Badruzaman, 'The Analysis of stock price at Indonesia Stock Exchange', Int. J. Recent Sci. Res., vol. Vol. 9, no. Issue 7(A).

[5] et al Alduneibat, 'The Impact of the tax planning in Industrial Public Joint Stock Companies upon the Performance of the Industrial Companies Listed in the Amman Stock Exchange Market', Account. Financ. Res., vol. Vol. 6, no. No.2, 2017.

[6] A. J. Auerbech, 'Measuring the effects of corporate tax cuts', J. Econ. Perfect, vol. Vol. 32, no. Number 4., 2018.

[7] N. M. Panda, B. \& Leepsa, 'Agency theory: Review of theory and evidence on problems and perspectives', Indian J. Corp. Gov., vol. 10(1), pp. 74-95., 2017.

[8] J. Kohlhase, S. and Pierk, 'The Effect of worldwide tax system on tax management of foreign subsidiaries.', 2019.

[9] N. Oats, L. \& Leepsa, 'Corporate tax avoidance: Is tax transparency the solution?', Account. Bus. Res., vol. Vol 40, no. No. 5., 2019.

[10] A. G. Gribnau, H.J.L.M. \& Jallai, 'Good tax governance: A Matter of moral responsibility and transparency', Nord. Tax J., p. pp 70-88., 2017.

[11] A. dan T. R. Crabtree, 'Corporate tax avoidance and the timeliness of annual earnings announcements.', Rev. Quant. Financ. Account., vol. Vol. 42 (1, pp. 51-67., 2012.

[12] et al. He, G., 'The Impact of corporate tax avoidance an analyst coverage and forecasts', Rev. Quant. Financ. Accounting., 2019.

[13] et al. Soebyakto, 'Investment opportunity set to earning quality and firms value: Corporate governance mechanism as moderating variable', Corp. Iwversh., vol. 14, no. issue 4, Summer., 2017.

[14] P. Scott, WR \& O'Brien, Financial Accounting Theory 8th Edition. Ontario: Pearson Canada Inc., 2020.

[15] X. X. Chen Zhao, Sheel Aditya, Shaomeng Wang, Jianmin Miao, 'A wideband microfabricated Ka-band planar helix slow-wave structur', IEEE Trans. Electron Devices, vol. 63, no. 7, pp. 2900-2906, 2016.

[16] R. Kormendi, R dan Lipe, 'Earnings innovation, earnings persistence, and stock return.', J. Bus., vol. 60:, pp. 323 - 345., 1987.

[17] S. P. Collins, D.W., and SP Kothari, 'An Analysis of intertemporal and cross-sectional determinant of earnings response coefficient', J. Account. Econ., pp. 143-182, 1989.

[18] F. Sri, M. \& Nur, 'Faktor-faktor yang mempengaruhi earnings response coefficient pada perusahaan yang terdaftar di BEJ', JAAI, vol. Volume 11, no. No.1, p. hal 35-45., 2007.

[19] Z. Mashayekhi, B. \& Aghel, 'A Study on the determinants of earnings response coefficient in an emerging market. Turkey: World Academy of Science', Eng. Technol. -Int. Soc. Behav. Educ. Econ. Bus. Ind. Eng., vol. Vol. 10, no. No. 7, pp. 2483 - 2486. 2016.

[20] Rofika, 'Faktor-faktor yang mempengaruhi earnings response coefficient (ERC) perusahaan manufaktur yang terdaftar di Bursa Efek Indonesia 2012', J. Akunt., vol. Vol. 3, no. No. 2, pp. 174 - 183., 2015.

[21] S. Hanlon, M. \& Heitzman, 'A review of tax research', J. Account. Econ., vol. 50, p. Pp 127 - 178., 2010.

[22] Yildirim, 'Behavioral finance or the efficient market hypothesis?', Int. J. Acad. Value Stud., vol. Vol. 03, no. Issue 11., 2017.

[23] F. Fridson, M \& Alvarez, Financial statement analysis: A Practitioner's guide, Third Edit. 2002.

[24] et al. Chen, CW, 'Financial statement comparability and the efficiency of acquisition 
decisions.', Spring, vol. Vol.35, no. issues 1., 2017.

[25] E. Fama, 'Efficient market: A Review of Theory and Empirical Work.', J. Finance, vol. 25 (2):, pp. 383-417., 1970.

[26] et al. Peon, D., 'A Guide on empirical tests of the EMH', 2018.

[27] Suwardjono, Teori Akuntansi Perekayasaan Pelaporan Keuangan., Edisi Keti. Yogyakarta: .: BPFE, 2014.

[28] et al. Dyreng, 'Long run corporate tax avoidance', Account. Rev., vol. Vol. 83, no. No.1, pp. 61-82., 2008.

[29] J. Slemrod, 'The Economic of Corporate Tax Selfishness', Natl. Tax J., vol. 56, pp. 877-899., 2004.

[30] A. S. Mulya, 'Effect generic strategy and value-added companies on enterprise sustainability with an investment opportunity as an intervening variable: empirical evidence of companies listed on IDX, MYS, PSE, SGX and set', Int. J. Econ. Res., vol. ISSN: 0972, no. Number 11.

[31] H. Ghozali, I. \& Latan, Konsep, teknik dan aplikasi smartPLS. Semarang: Badan Penerbit Universitas Diponegoro., 2015.

[32] R. E. Hair, J. F., Black, W. C., Babin, B. J., \& Anderson, 'Multivariate data analysis: A global perspective (7th ed.)', New Jersey Pearson Educ. Inc., 2010.

[33] D. Priyatno, Mandiri belajar analisis data dengan SPSS. Yogyakarta (ID): Mediakom., 2012.

[34] A. Martani, D. \& dan Persada, 'Pengaruh book tax gap terhadap persistensi laba.', $J$. Akunt. dan Keuang. Indones., vol. Volume 7, no. No. 2., 2010. 